\title{
REPRESENTASI BRAND IDENTITY DALAM WEBSERIES SEBAGAI ALTERNATIF MEDIA PERIKLANAN
}

\author{
Dian Tamitiadini ${ }^{1}$, Dea Lutfianto ${ }^{2 *}$ \\ 1) Ilmu Komunikasi, Universitas Brawijaya \\ 2) Ilmu Komunikasi, Universitas Brawijaya
}

\begin{abstract}
In the era of globalization, the Internet is growing rapidly. One proof of the development of the internet is the emergence of a social media platform that can change the way people live in the field of communication, health, business and others. One of the social media that is often used is Youtube. And the content created by brands that continue to experience positive trends from year to year is webseries. This research uses Charles Sanders Peirce semiotic analysis method. The Peirce Semiotics Method is used to see representation of brand identity present at Jelang Buka from Unilever, Sore from Tropicana Slim and Balada Al Prilly from Vivo. The findings of the research show that Tropicana Slim with Sore webseries is more implicit in conveying brand identity to the audience by prioritizing a healthy lifestyle campaign. While Unilever with Jelang Buka webseries and Vivo with Balada Al Prilly webseries explicitly conveys identity by bringing up their products in every episode. The brand identity that appears in the three webseries is represented so neatly and flows together with the story of the webseries so that the audience can enjoy the advertisement with the story presented by each brand without having to force the ad to see it. As a practical suggestion many brands in all sectors can consider creating ads using webseries on Youtube because they have a large number of viewers and for brands that have made the webseries consistent with other stories or continuing stories. The academic advice is expected to do further research in the field of quantitative to see the effectiveness of webseries as a medium of advertising on consumer buying considering it has many audiences.

Keyword: Brand Identity, Webseries, Youtube, Advertisement, Semiotic.
\end{abstract}

\begin{abstract}
ABSTRAK
Di era globalisasi, internet berkembang semakin pesat. Salah satu bukti berkembangnya internet adalah munculnya sebuah platform media sosial yang dapat mengubah cara hidup masyarakat di bidang komunikasi, kesehatan, bisnis dan lain-lain. Dan salah satu media sosial yang sering digunakan adalah Youtube. Dan konten yang dibuat oleh brand yang terus mengalami tren positif dari tahun ke tahun adalah webseries. Penelitian ini menggunakan metode analisis semiotika Charles Sanders Peirce. Metode Semiotika Peirce digunakan untuk melihat representasi brand identity yang hadir di webseries Jelang Buka dari Unilever, Sore dari Tropicana Slim dan Balada Al Prilly dari Vivo. Penemuan hasil penelitian menunjukka yaitu Tropicana Slim dengan webseries Sore lebih implisit dalam menyampaikan identitas merek kepada penontonnya dengan mengutamakan kampanye gaya hidup sehat. Sementara Unilever dengan webseries Jelang Buka dan Vivo dengan webseries Balada Al Prilly dalam menyampaikan identitas secara eksplisit dengan memunculkan produk-produknya di setiap episode. Identitas merek yang dimunculkan di ketiga webseries tersebut di representasikan begitu rapih dan mengalir menjadi satu dengan cerita webseries tersebut sehingga penonton dapat menikmati iklan dengan cerita yang disuguhkan masing-masing brand tanpa harus memaksa melihat iklan tersebut. Sebagai saran praktis diharpakan berbagai brand di segala bidang dapat mempertimbangkan untuk membuat iklan menggunakan webseries di Youtube karena memiki jumlah penonton yang banyak dan bagi brand yang telah membuat webseries tetap konsisten denga membuat cerita-certa lain atau melanjutkn cerita sebelumnya. Adapun saran akademik yang diharapkan agar dilakukannya penelitian
\end{abstract}

\footnotetext{
* Korespondensi Penulis

Email: dealutfianto@gmail.com
} 
lanjutan di bidang kuantitatif untuk melihat efektifitas webseries sebagai media periklanan terhadap minat beli masyarakat mengingat jumlah penonton yang banyak di tren webseries ini.

Kata Kunci: Brand Identity, Webseries, Youtube, Periklanan, Semiotika

\section{PENDAHULUAN}

Di era globalisasi ini, internet mengalami perkembangan yang begitu pesat. Dimitria (2011) menyatakan kebutuhan setiap orang terhadap internet semakin besar. Menurut Suryawinata (2013) hal tersebut membuat internet menjadi salah satu media yang dapat digunakan untuk berbagai keperluan. Salah satu bukti dari kegunaan internet adalah hadirnya media sosial di tengah-tengah masyarakat. Suryawinata (2013) menyatakan bahwa saat ini sudah tercatat lebih dari 2,4 milyar pengguna internet dari seluruh dunia yang pasti akan mengakses media sosial secara rutin. Menurut Amedie (2015) media sosial merupakan sebuah forum baru yang di mana para penggunanya dapat berpartisipasi di dalamnya dan saling berbagi informasi antara satu pengguna dengan pengguna lainnya serta menghilangkan batas komunikasi karena semua dapat terhubung melalui media sosial. Menurut lembaga survey internasional we are social (2017) beberapa contoh media sosial yang saat ini sering digunakan adalah Facebook, YouTube, Whatsapp, Facebook Messenger dan Instagram.

Menurut Yuniar (2015) YouTube saat ini merupakan salah satu platform media sosial terpopuler di Indonesia dengan pertumbuhan jumlah video yang diunggah pengguna terbesar di kawasan Asia Pasifik. Aliya (2018) menyatakan bahwa YouTube merupakan situs yang memfasilitasi penggunanya untuk berbagi video yang mereka miliki atau sebatas menikmati berbagai video yang diunggah ke situs YouTube melalui internet. Veronica selaku Head of Marketing Google Indonesia (Dikutip dari Yuniar, 2015) memaparkan sepuluh konten YouTube yang paling banyak ditonton di Indonesia, yakni musik di posisi pertama, disusul oleh tutotrial, komedi, cuplikan film, film asing, user generated content, pendidikan, hiburan, sepak bola, dan gaya hidup. YouTube memiliki berbagai fitur yang membuat penggunanya merasa dimudahkan baik dari sisi content creator maupun dari sisi penontonnya. Menurut Alfajri, Irfansyah, \& Isdianto (2014) menyatakan bahwa YouTube semakin diminati karena kemudahan fitur yang ditawarkan dan gratis tanpa biaya. Hal tersebut menjadi peluang bagi brand untuk mengiklankan produk atau jasa mereka dengan kesempatan yang semakin besar untuk diterima oleh target pasar melalui platform YouTube. Menurut Antony (2015) hal tersebut dapat terjadi karena pengiklan dapat mengatur di mana iklannya akan tampil dan siapa yang akan melihat iklannya. Sehingga membuat kemungkinan iklan yang ditampilkan mencapai pelanggan yang berpotensi berdasarkan penargetan keyword, topic, dan demographic dan pengiklan juga dapat menargetkan berdasarkan umur, jenis kelamin dan lokasi.

Melalui cretor academy.YouTube.com (2015) dapat diketahui berbagai format Adsense untuk beriklan bagi sebuah produk yaitu diantaranya adalah iklan bergambar, iklan hamparan, iklan video yang dilewati, iklan video yang tidak dapat dilewati, iklan paruh-putar, iklan bumper, dan iklan seluler biasa. Dengan adanya jenisjenis iklan yang muncul di tampilan YouTube terutama untuk iklan video yang dapat dilewati membuat iklan yang tampil di laman YouTube terkesan seperti iklan yang ada di televisi.

Namun demikian, iklan yang tampil di internet pada penelitian yang dilakukan oleh Hariningsih \& Munarsih (2006) seringkali dihindari oleh pengunjung karena persepsi penghindaran tujuan. Semakin tinggi tingkat penghindaran tujuan, maka semakin tinggi pula penghindaran iklan. Harnigsih \& Munarsih mengatakan bahwa persepsi penghindaran tujuan yang dirasakan oleh periklanan secara signifikan mampu mempengaruhi penghindaran iklan di internet. Sehingga pengguna internet 
menganggap bahwa iklan melalui internet dirasakan lebih mengganggu dibandingkan dengan iklan di media konvensional seperti televisi. Lanjut Hariningsih \& Munarsih menyatakan bahwa ketika iklan di internet menjadi sumber gangguan yang signifikan serta menghambat usaha untuk mengakses isi web dan mengalihkan perhatian para pengguna internet serta mengganggu pencarian informasi, maka konsumen cenderung menghindari iklan tersebut. Hal tersebut juga terjadi pada pengunjung YouTube. Iklan melalui YouTube Adsense yang muncul di awal video dari sebuah channel dari content creator dianggap sebagai sumber gangguan yang signifikan serta menjadi penghambat untuk melihat video di channel tersebut dan para pengunjung akan melakukan penghindaran terhadap iklan tersebut dengan cara melakukan skip iklan yang ada pada video di channel content creator yang bersangkutan. Lalu menurut Kelly et al,. (dikutip dari Hariningsih \& Munarsih 2006) menambahkan juga bahwa ketika iklan mengurangi atau menginterupsi kecepatan pencarian dan pemrosesan data dalam hal ini menonton video di YouTube, konsumen dapat bereaksi negatif terhadap kredibilitas media iklan internet tersebut dengan berbagai format iklan online seperti banner, pop up, floating ad, skyscraper, dan lain-lain yang membutuhkan tindakan konsumen dapat merangsang konsumen untuk langsung menghapus pesan iklan atau menghindarinya.

Hal tersebut membuat para pengiklan mencari alternatif lain untuk beriklan melalui media digital. Peneliti menemukan tren baru saat ini yang dilakukan oleh para pengiklan di Indonesia yaitu dengan cara membuat konten kreatif periklanan melalui webseries di channel YouTube merek terkait. Menurut situs ideaimaji.com (2017), webseries merupakan sebuah format sinema berseri yang diracang untuk ditayangkan melalui teknologi TV berbasis web atau yang biasa disebut dengan webisode. Genre yang ditawarkan di webseries juga tidak terlalu jauh beda dengan series yang ada pada televisi seperti horor, komedi, romance, thriller dan lain-lain.

Adapun sejarah webseries di dunia yang dijelaskan dalam jurnal dari Alfajri, Irfansyah \& Isdianto (2014) menjelaskan bahwa webseries pertama kali diproduksi oleh Bullseye Art pada tahun 1995 dengan materi serial animasi pendek. Dengan beberapa judul yang cukup populer adalah Miss Muffy and the Muf Mob dan Space Dog. Dan untuk brand yang mengeluarkan webseries pertama kali adalah Microsoft dengan judul "weird TV 2000". Di tahun 2003 hingga 2006. Beberapa seri dari webseries mencapai popularitasnya. Hal ini ditandai dengan Perusahaan produksi Rooster Teeth yang memproduksi video Red $V s$ Blue yang sudah mencapai lebih dari 100 juta penonton yang ditayangkan di YouTube Menurut Yani (2017) di Indonesia, webseries mulai terekspos di tahun 2012 saat Dennis Adhiswara, Bonni Rambatan, dan Camelia Jonathan mendirikan komunitas webseries Indonesia. Menurut Alfajri, Irfansyah \& Isdianto (2014) mengatakan bahwa webseries di Indonesia hadir karena adanya dorongan dari para content creator untuk membuat video dan mengunggahnya di YouTube melalui saluran atau channel pribadi. Menurut situs hiburan.metrotvnews.com (2017) munculnya webseries ke tengah-tengah masyarakat menunjukkan adanya indikasi bahwa webseries hadir sebagai media alternatif menonton tayangan yang ada di televisi. Yani (2017) mengatakan bahwa konten webseries yang cukup terkenal pertama kali yang hadir di Indonesia adalah adalah webseries malam miggu Miko dan webseries Jalan-jalan Men yang telah mendapatkan jutaan penonton setiap episodenya. Yani menambahkan bahwa kesuksesan webseries malam minggu miko dan Jalan-jalan men di Indonesia membuat beberapa brand memanfaatkan peluang tersebut sebagai media alternatif periklanan yang bersifat softselling sebagai salah satu bentuk dari media komunikasi pemasaran.

Di Indonesia, brand yang mengiklankan produknya melalui konten 
webseries di YouTube sudah dimulai sejak tahun 2014 yaitu brand XL dan Smartfren ( Lihat tabel 1). Di tahun 2014, brand-brand yang membuat webseries masih sangat sedikit karena masyrakat Indonesia masih banyak yang belum mengetahui Webseries di internet. Hal tersebut dapat dilihat dari jumlah penonton yang menonton webseries di Indonesia masih sangat sedikit. Dari dua webseries yang peneliti observasi. Webseries tersebut memiliki jumlah total penonton sebanyak 228.710 orang.

\begin{tabular}{|c|c|c|c|c|c|c|}
\hline No. & $\begin{array}{c}\text { Nama } \\
\text { brand }\end{array}$ & $\begin{array}{c}\text { Jenis } \\
\text { produk }\end{array}$ & $\begin{array}{c}\text { Judul } \\
\text { Webseries }\end{array}$ & $\begin{array}{c}\text { Jumlah } \\
\text { episode }\end{array}$ & $\begin{array}{c}\text { Tanggal } \\
\text { Publish }\end{array}$ & $\begin{array}{c}\text { Jotal } \\
\text { Jumlah } \\
\text { Penonton }\end{array}$ \\
\hline 1 & $\begin{array}{c}\text { XL } \\
\text { AXIATA }\end{array}$ & $\begin{array}{c}\text { Card } \\
\text { Provider }\end{array}$ & $2^{\text {nd }}$ Chance & $\begin{array}{c}\text { Ep1- } \\
\text { Ep10 }\end{array}$ & $\begin{array}{c}10 \\
\text { September } \\
2014\end{array}$ & $\begin{array}{c}191.753 \\
\text { orang }\end{array}$ \\
\hline 2 & Smartfren & $\begin{array}{c}\text { Card } \\
\text { Provider }\end{array}$ & EksisStories & $\begin{array}{c}\text { Ep1- } \\
\text { Ep4 }\end{array}$ & $\begin{array}{c}28 \text { Mei } \\
2014\end{array}$ & $\begin{array}{c}36.957 \\
\text { orang }\end{array}$ \\
\hline
\end{tabular}

Tabel 1. Kategori Webseries Di YouTube tahun 2014 Sumber: www.YouTube.com

Ditahun 2016, jumlah brand yang membuat webseries semakin banyak. Terdapat 6 (enam) Brand membuat tayangan webseries (Lihat tabel 2). Di tahun ini pun mulai beragam genre yang ditayangkan di Webseries Indonesia mulai dari romance, action, biography dan comedy.

\begin{tabular}{|c|c|c|c|c|c|c|}
\hline No. & $\begin{array}{l}\text { Nama } \\
\text { brand }\end{array}$ & $\begin{array}{c}\text { Jenis } \\
\text { produk }\end{array}$ & $\begin{array}{c}\text { Judul } \\
\text { Webseries }\end{array}$ & $\begin{array}{l}\text { Jumlah } \\
\text { episode }\end{array}$ & $\begin{array}{l}\text { Tanggal } \\
\text { Publish }\end{array}$ & $\begin{array}{c}\text { Total } \\
\text { Jumlah } \\
\text { Penonton }\end{array}$ \\
\hline 1 & Telkomsel & Provider & $\begin{array}{l}\text { Pulang- } \\
\text { pulang } \\
\text { gantens s1 }\end{array}$ & $\begin{array}{l}\text { Ep1- } \\
\text { Ep30 }\end{array}$ & $\begin{array}{l}6 \text { Juni } \\
2016\end{array}$ & $\begin{array}{c}1.703 .915 \\
\text { orang }\end{array}$ \\
\hline 2 & AXE & Perfume & $\begin{array}{c}\text { The Untold } \\
\text { Story }\end{array}$ & $\begin{array}{l}\text { Ep1- } \\
\text { Ep10 }\end{array}$ & $\begin{array}{l}8 \mathrm{Mei} \\
2016\end{array}$ & $\begin{array}{c}17.310 .910 \\
\text { orang }\end{array}$ \\
\hline 3 & Smartfren & $\begin{array}{c}\text { Card } \\
\text { Provider }\end{array}$ & $\begin{array}{c}\text { Balada } \\
\text { Ramadhan } \\
\text { si Arief } \\
\text { Muhammad }\end{array}$ & $\begin{array}{l}\text { Ep1- } \\
\text { Ep5 }\end{array}$ & $\begin{array}{l}20 \text { Juni } \\
2016\end{array}$ & $\begin{array}{c}781.615 \\
\text { orang }\end{array}$ \\
\hline 4 & Wardah & Outfit & $\begin{array}{c}\text { Hijab Love } \\
\text { Story }\end{array}$ & $\begin{array}{l}\text { Ep1- } \\
\text { Ep6 }\end{array}$ & $\begin{array}{l}\text { 1 Juni } \\
2016\end{array}$ & 1.791 .124 \\
\hline 5 & Wardah & Outfit & $\begin{array}{c}\text { Hijab Love } \\
\text { Story } 2\end{array}$ & $\begin{array}{l}\text { Ep1- } \\
\text { Ep4 }\end{array}$ & $\begin{array}{c}9 \\
\text { Oktober } \\
2016\end{array}$ & 745.234 \\
\hline 6 & Floridina & $\begin{array}{l}\text { Food and } \\
\text { Beverage }\end{array}$ & $\begin{array}{c}\text { Fog } \\
\text { Mission }\end{array}$ & $\begin{array}{l}\text { Ep1- } \\
\text { Ep12 }\end{array}$ & $\begin{array}{c}30 \\
\text { Maret } \\
2016\end{array}$ & $\begin{array}{c}13.071 \\
\text { orang }\end{array}$ \\
\hline
\end{tabular}

Tabel 2. Kategori Webseries Di YouTube tahun 2016

Sumber: www. YouTube.com 
Dan di tahun 2017, brand yang membuat tayangan webseries terus berkembang. Terdapat 12 (dua belas) brand membuat tayangan webseries (Lihat tabel 3). Konten yang disajikanpun makin beragam, ada yang melanjutkan dari seri sebelumnya dan ada pula yang baru memulai untuk membuat tayangan webseries di YouTube. Hal tersebut menunjukkan bahwa webseries semakin digemari di Indonesia. Sehingga beberapa brand berlomba-lomba membuat tayangan webseries untuk dinikmati penonton.

\begin{tabular}{|c|c|c|c|c|c|c|}
\hline No. & $\begin{array}{l}\text { Nama } \\
\text { brand }\end{array}$ & $\begin{array}{l}\text { Jenis } \\
\text { produk }\end{array}$ & $\begin{array}{c}\text { Judul } \\
\text { Webseries }\end{array}$ & $\begin{array}{l}\text { Jumlah } \\
\text { episode }\end{array}$ & $\begin{array}{l}\text { Tanggal } \\
\text { Publish }\end{array}$ & $\begin{array}{c}\text { Total } \\
\text { Jumlah } \\
\text { Penonton } \\
\end{array}$ \\
\hline 1 & Telkomsel & Provider & $\begin{array}{l}\text { Pulang- } \\
\text { pulang } \\
\text { gantens s2 }\end{array}$ & Ep1-Ep30 & $\begin{array}{l}27 \text { Mei } \\
2017\end{array}$ & $\begin{array}{c}2.064 .185 \\
\text { orang }\end{array}$ \\
\hline 2 & $\begin{array}{l}\text { Tropicana } \\
\text { Slim }\end{array}$ & $\begin{array}{l}\text { Food and } \\
\text { Beverage }\end{array}$ & $\begin{array}{l}\text { Sore-Istri } \\
\text { dari masa } \\
\text { depan }\end{array}$ & Ep1-Ep9 & $\begin{array}{l}31 \text { Januari } \\
2017\end{array}$ & $\begin{array}{c}9.600 .075 \\
\text { orang }\end{array}$ \\
\hline 3 & Samsung & $\begin{array}{l}\text { Technology } \\
\text { and gadget }\end{array}$ & $\begin{array}{l}\text { Move On } \\
\text { Trip }\end{array}$ & Ep1-Ep4 & $\begin{array}{l}2 \text { Agustus } \\
2017\end{array}$ & $\begin{array}{c}3.993 .818 \\
\text { orang }\end{array}$ \\
\hline 4 & AXE & Perfume & $\begin{array}{c}\text { The } \\
\text { Documentary }\end{array}$ & Ep1-Ep6 & $\begin{array}{c}28 \text { Maret } \\
2017 \\
\end{array}$ & $\begin{array}{c}5.849 .325 \\
\text { orang }\end{array}$ \\
\hline 5 & $\begin{array}{l}\text { Malang } \\
\text { Strudel }\end{array}$ & $\begin{array}{l}\text { Food and } \\
\text { Beverage }\end{array}$ & $\begin{array}{c}\text { Malang } \\
\text { Melintang }\end{array}$ & Ep1-Ep24 & $\begin{array}{l}4 \text { April } \\
2017\end{array}$ & $\begin{array}{c}216.850 \\
\text { orang }\end{array}$ \\
\hline 6 & Smartfren & $\begin{array}{c}\text { Card } \\
\text { Provider }\end{array}$ & $\begin{array}{c}\text { Semua Gara- } \\
\text { Gara Saaih } \\
\text { Halilintar }\end{array}$ & Ep1-Ep3 & $\begin{array}{l}\text { 12 Juni } \\
2017\end{array}$ & $\begin{array}{c}5.359 .657 \\
\text { orang }\end{array}$ \\
\hline 7 & Wardah & Make Up & $\begin{array}{l}\text { Hijab Love } \\
\text { Story } 3\end{array}$ & Ep1-Ep4 & $\begin{array}{l}29 \text { Januari } \\
2017\end{array}$ & $\begin{array}{c}584.740 \\
\text { orang }\end{array}$ \\
\hline 8 & Eiger & $\begin{array}{c}\text { Outdoor } \\
\text { Equipment }\end{array}$ & $\begin{array}{c}\text { Dunia Dalam } \\
\text { Kita } \\
\end{array}$ & Ep1-Ep20 & $\begin{array}{l}27 \text { Mei } \\
2017 \\
\end{array}$ & $\begin{array}{c}1.651 .433 \\
\text { orang }\end{array}$ \\
\hline 9 & Unilever & $\begin{array}{l}\text { Daily life } \\
\text { goods }\end{array}$ & Jelang Buka & Ep1-Ep4 & $\begin{array}{l}2 \text { Juni } \\
2017\end{array}$ & $\begin{array}{c}13.402 .380 \\
\text { orang }\end{array}$ \\
\hline 10 & Traveloka & Technology & $\begin{array}{c}\text { Arief } \\
\text { Muhammad } \\
\text { x Traveloka }\end{array}$ & Ep1-Ep6 & $\begin{array}{c}\text { 14 Juni } \\
2017\end{array}$ & $\begin{array}{c}2.822 .349 \\
\text { orang }\end{array}$ \\
\hline 11 & $\mathrm{~V}$ & $\begin{array}{l}\text { Gadget and } \\
\text { smartphone }\end{array}$ & $\begin{array}{c}\text { Balada Al } \\
\text { Prilly }\end{array}$ & Ep1-Ep3 & $\begin{array}{l}6 \text { Agustus } \\
2017\end{array}$ & $\begin{array}{c}7.197 .662 \\
\text { orang }\end{array}$ \\
\hline
\end{tabular}

Tabel 3. Kategori Webseries Di YouTube tahun 2017

Sumber: www.YouTube.com

Sehingga dapat dikatakan bahwa perkembangan brand yang membuat iklan dalam bentuk webseries di Indonesia terus mengalami peningkatan setiap tahunnya (lihat Gambar 1.1). Hal tersebut dapat dilihat dari jumlah merek yang membuat iklan melalui webseries ataupun jumlah penonton yang terus meningkat setiap tahunnya. Animo masyarakat terhadap tayangan
Webseries dinilai positif bagi merek-merek terkait karena mereka dapat melihat feedback penonton dari video yang dibuat. Menurut Rahayu (2017) banyak keuntungan membuat webseries di YouTube salah satu diantaranya adalah video produksi yang lebih murah dibandingkan untuk tvc. Hal tersebut juga menjadi salah satu alasan 
brand atau merek terkait membuat webseries di YouTube.

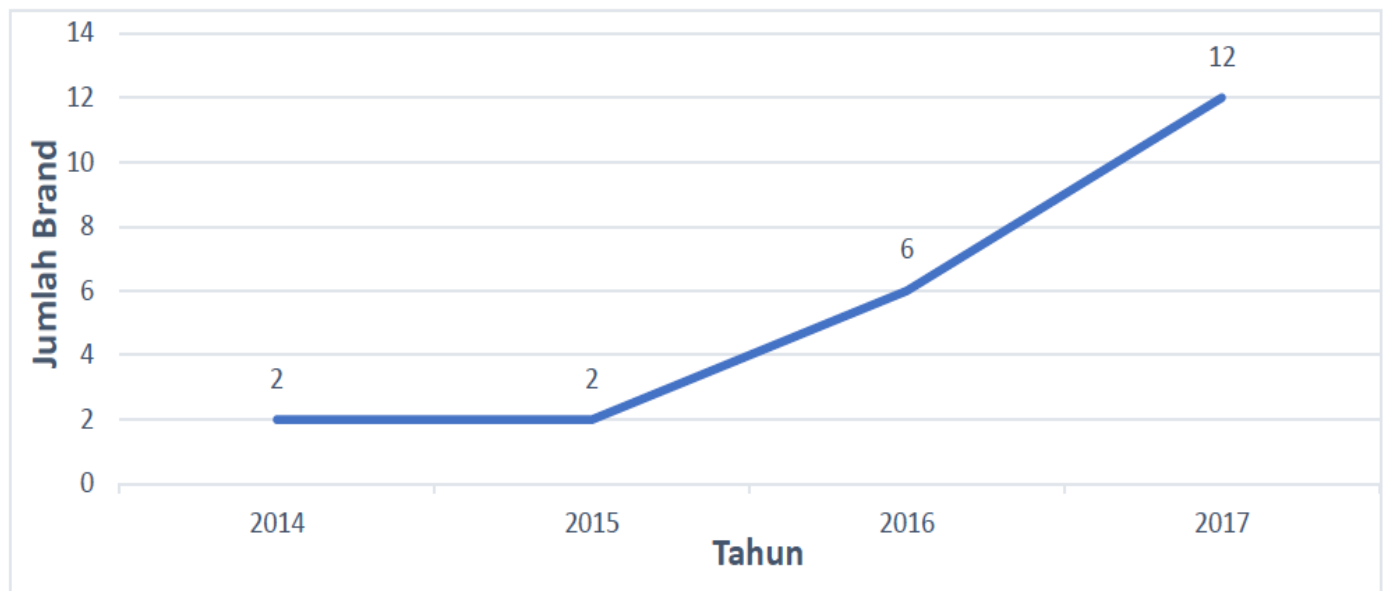

Gambar 1. Pertumbuhan brand yang membuat tayangan webseries di Youtube Indonesia Sumber : Data olahan pribadi

Terdapat 3 (tiga) brand yang penulis pilih dari 12 (dua belas) brand yang ada di tahun 2017 dengan jumlah penonton yang paling banyak yaitu diantaranya adalah Unilever yang memiliki tayangan webseries berjudul Jelang Buka, Tropicana Slim yang memiliki tayangan webseries berjudul Soreistri dari masa depan, dan Vivo yang memiliki tayangan webseries berjudul Balada AlPrilly. Ketiga brand tersebut berasal dari kategori brand yang berbeda-beda namun tetap menggunakan webseries sebagai media alternatif periklanan.

Sebagai salah satu bentuk media alternatif periklanan, webseries menampilkan identitas dari produk yang menjadi ciri khas suatu merek. Menurut Sadat $(2009, \mathrm{~h} .48)$ brand identity adalah ciri-ciri yang diharapkan melekat di benak pelanggan. Ia melanjutkan bahwa saat pelanggan mendengar atau melihat dari sebuah brand maka pelanggan akan segera mendapatkan banyak informasi mengenai merek tersebut. Sehingga kegitatan beriklan melalui webseries mempunyai penggambaran identitas merek tersendiri. Terdapat berbagai model yang menjelaskan unsur-unsur terbentuknya identitas merek (brand identity), salah satunya model dari Aaker. Aaker (dikutip dari Gultom 2014) membagi identitas merek menjadi dua belas dimensi yang terdiri dari empat perspektif yaitu brand sebagai sebuah produk (brand as product) yang memiliki dimensi lingkup produk (product scope), atribut produk (product attributes), kualitas atau nilai (quality/value), pemakaian atau penggunaan (uses), pengguna (users) dan negara asal (country of origin), perspektif kedua yaitu brand sebagai sebuh organisasi (brand as organization) yang mempunyai dimensi atribut organisasi atau perusahaan (organizational attributes) dan dimensi local versus Global, perpekstif ketiga yaitu brand sebagai seseorang (brand as person) yang memiliki dimensi berupa kepribadian brand (brand personality) dan dimensi brand customer relationship, dilanjutkan perspektif terakhir yaitu brand sebagai sebuah simbol (brand as symbol) yang memiliki dimensi citra visual (visual imagery/metaphors) dan dimensi brand heritage.

Menurut Puspa (2017) video-video periklanan dalam webseries terdapat pesan- 
pesan dari identitas merek atau brand identity secara tersirat yang ingin disampaikan karena bentuk kegiatan komunikasi pemasarannya bersifat soft selling. Sehingga dibutuhkan pemahaman atau representasi dari sebuah makna untuk dikaji lebih lanjut menggunakan analisis teks yaitu analisis Semiotika. Hal tersebut membuat peneliti memilih judul dalam penelitian ini yaitu Representasi Brand Identity dalam webseries sebagai alternatif media periklanan (Analisis Semiotika Peirce dalam webseries Jelang Buka, Sore, dan Balada Al Prilly). Penelitian ini menjadi penting karena mencoba untuk menjelaskan bagaimana perkembangan media periklanan khususnya di tahap penggunaan media alternatif melalui internet sebagai medium penyampaian konten kreatif periklanan. Sebagai bentuk media komunikasi pemasaran, webseries bersifat softselling sehingga brand identity dari produk tersebut dapat menjangkau konsumen dengan tepat sasaran. Melalui metode analisis semiotika milik Peirce, peneliti ingin menjelaskan keterkaitan antara representament, object, dan interpretan yang terdapat dalam webseries Jelang Buka, Sore, dan Balada Al-Prilly.

\section{Rumusan Masalah}

Bagaimanakah representasi brand identity

dalam konten kreatif periklanan yang

dikemas dalam webseries Jelang Buka, Sore, dan Balada Al Prilly digambarkan?

\section{TINJAUAN PUSTAKA}

\section{Brand identity (Identitas Merk)}

Menurut Sadat (2009; 48) Identitas merek adalah ciri-ciri yang diharapkan dapat melekat di benak pelanggan. Ia menambahkan bahwa saat mendengar atau melihat dari sebuah brand maka pelanggan akan segera mendapatkan banyak informasi mengenai merek tersebut. Dari pendapat tersebut dapat dikatakan bahwa Brand identity atau identitas merek merupakan sebuah identitas yang dimiliki perusahaan atau produk yang menjadi pembeda dengan perusahaan atau produk lainnya yang ingin dikomunikasikan kepada konsumen dan pelanggan untuk menciptakan persepsi konsumen atau pelanggan yang relevan. Hal tersebut sejalan dengan pernyataan Gultom (2014) yang menjelaskan bahwa identitas pada dasarnya mengekspresikan hal-hal yang menyangkut sebuah brand dan identitas juga memiliki fungsi untuk mengatur persepsi perusahaan sekaligus memperlihatkan dan menguatkan aspek diferensiasi sebuah merek produk atau jasa. Apabila identitas merek tersebut kuat, maka kemungkinan merek atau brand akan mampu bersaing dengan para kompetiror yang hadir. Menurut Sadat (2009,h. 48) melalui identitas, sebuah objek dapat mewakilkan berbagai asosiasi pada sebuah brand atau merek.

Terdapat sebuah model Brand identity dari Aaker (dikutip dari Gultom 2014) yang membagi identitas merek menjadi dua belas dimensi yang terdiri dari empat perspektif yaitu brand sebagai sebuah produk (brand as product) yang memiliki dimensi lingkup produk (product scope), atribut produk (product attributes), kualitas atau nilai (quality/value), pemakaian atau penggunaan (uses), pengguna (users) dan negara asal (country of origin), perspektif kedua yaitu brand sebagai sebuh organisasi (brand as organization) yang mempunyai dimensi atribut organisasi atau perusahaan (organizational attributes) dan dimensi local vs global, perpekstif ketiga yaitu brand sebagai seseorang (brand as person) yang memiliki dimensi berupa kepribadian brand (brand personality) dan pelanggan brand (Brand customer relationship), selanjutnya perspektif yang terakhir yaitu brand sebagai sebuah simbol (brand as symbol) yang memiliki dimensi citra visual (visual imagery/metaphors), dan peninggalan brand (brand heritage). Menurut Gultom (2014) tidak semua proses brand identity membutuhkan semua perspektif dan dimensi. Adapun penjabaran 12 (dua belas) dimensi dari 4 (empat) perspektif berdasarkan teori Brand identity dari Aaker (dikutip dari Gultom 2014) adalah sebagai berikut : 


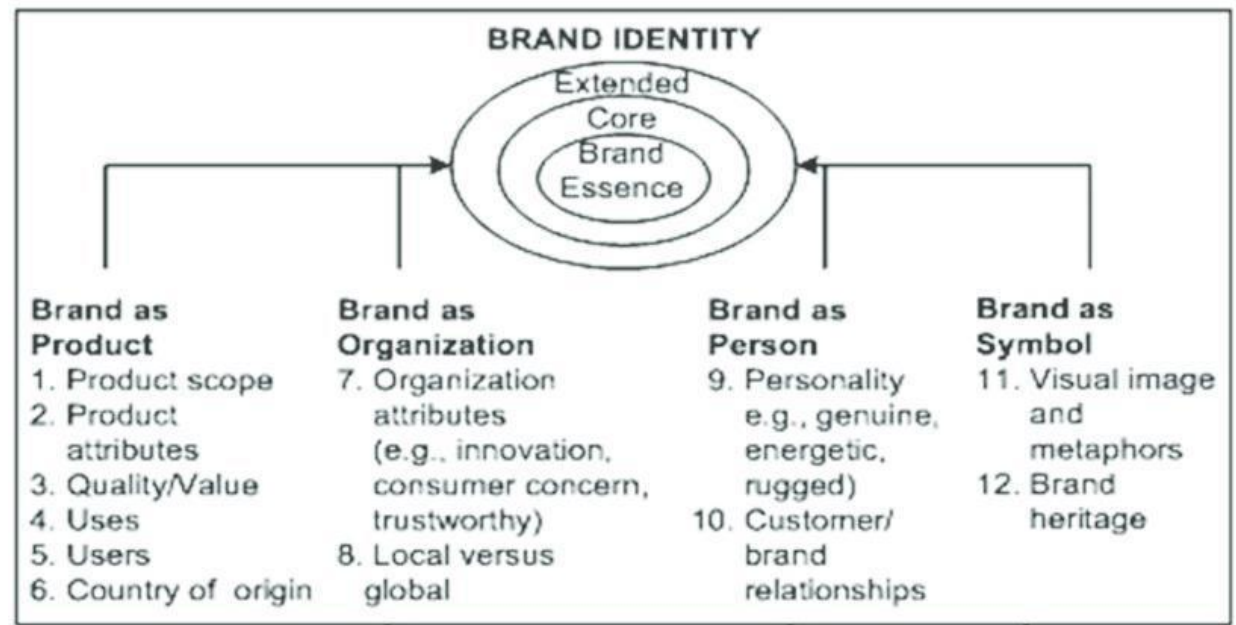

Gambar 2. Model Brand Identity Aaker

Sumber: Gultom (2014)

a. Brand as Product

- Product Scope

Product Scope berkaitan dengan "dengan produk apakah sebuah brand diasosiasikan?”. Kuatnya hubungan sebuah produk dengan asosiasinya dapat diartikan sebagai brand yang akan diingat kembali apabila terdapat sebuah tanda kategori produk disebutkan.

- Product attribute

Product attribute berkaitan dengan pembelian atau penggunaan sebuah produk yang dapat memberikan manfaat fungsional dan manfaat emosional. Hal tersebut didukung dengan adanya penawaran akan sesuatu yang lebih baik atau sesuatu yang extra seperti service atau pelayanan.

- Quality/value

Quality/value berkaitan dengan situasi pentingnya suatu produk brand dikhususkan apabila dibandingkan dengan produk brand lainnya berdasarkan kualitas yang menempel pada brand tersebut.

- Uses

Uses berkaitan dengan situasi dimana sebuah brand mencoba menciptakan ciri khas dalam menjual produknya.

- Users
Users berkaitan dengan tipe pengguna brand. Users bertujuan untuk para pengguna yang berada pada suatu interest yang berkaitan dengan brand.

- Country of Origin

Country of origin berkaitan dengan sebuah brand yang diasosiasikan dengan negara asalnya.

b. Brand as Organization

- Organizational attributes

Organizational attributes berkaitan dengan sebuah brand yang lebih mengutamakan atribut atau nilai perusahaan dibandingkan dengan produk atau jasa.

- Local versus Global

Local versus Global berkaitan dengan sebuah kegiatan dalam organisasi brand mengikuti aktivitas global atau menyesuaikan dengan budaya lokalnya.

c. Brand as Person

- Brand personality

Brand personality berkaitan dengan penciptaan karakter atau kepribadian brand dalam rangka menguatkan brand.

- Brand customer relationship

Brand customer relationship berkaitan dengan kepribadian brand yang dapat 
membantu mengomunikasikan manfaat fungsional.

\section{d. Brand as Symbol}

- Visual imagery/methaphors

Visual imagery/metaphor berkaitan dengan identitas yang mempermudah untuk memperoleh pengenalan dan pengingatan kembali akan sebuah brand.

- Brand heritage

Brand heritage berkaitan dengan pengalaman atau peninggalan yang ingin disampaikan sebuah brand.

Adapun brand identity digunakan dalam penelitian ini sebagai dasar penelitian untu mengetahui penggamabran identitas merek yang hadir di dalam webseries Jelang Buka, Sore, dan Balada Al Prilly.

\section{Periklanan}

Menurut Nurrofiq (2012) periklanan merupakan suatu bentuk komunikasi yang memiliki tujuan untuk mengajak orang yang melihat, membaca atau mendengarnya untuk melakukan sesuatu. Hal senada disampaikan oleh Sora (2015) yang menyatakan bahwa periklanan adalah suatu penyajian materi atau pesan secara persuasif kepada masyrakat melalui media massa yang bertujuan untuk mempromosikan produk ataupun jasa yang dijual oleh perusahaan. Jefkins dalam Yusuf (2010) menjelaskan bahwa periklanan sebagai pesan penjualan yang paling persuasif dan ditargetkan kepada pembeli potensial terkait produk yang telah ditetapkan dengan biaya serendah-rendahnya. Dari berbagai pengertian diatas dapat disimpulkan bahwa periklanan merupakan sebuah alat untuk mempersuasi atau mengajak konsumen agar melakukan hal yang diinginkan oleh perusahaan yaitu membeli produk atau jasa perusahaan tersebut dengan biaya serendahrendahnya. Dikarenakan salah satu sifat dari iklan tersebut untuk mempersuasi sehingga efek dari iklan tersebut adalah meningkatnya brand awareness dari masyarakat. Sehingga iklan menjadi salah satu hal penting yang harus dipertimbangkan oleh sebuah perusahaan.
Namun, menurut Shimp (2000, h.354) efek dari periklanan yang tidak pasti dan memerlukan jangka waktu yang cukup panjang membuat perusahaan berpikir untuk mengurangi pengeluaran-pengeluaran iklan atau mengurangi iklan secara keseluruhan. Dan pengeluaran yang dikurangi untuk periklanan merupakan tambahan keuntungan perusahaan. Lanjut, menurut Shimp, alasan lain perusahaan mengurangi biaya untuk beriklan adalah karena profit besar yang didapatkan perusahaaan sehingga perusahaan tidak perlu beriklan. Hal tersebut terlihat bahwa perusahaan kurang menyadari pentingnya periklanan sebagai investasi jangka Panjang.

Menurut Shimp (2000, h. 357) terdapat lima fungsi periklanan yaitu informing (memberi informasi), persuading (mempersuasi), reminding (mengingatkan), adding value (memberikan nilai tambah), dan assisting (mendampingi). Informing mempunyai arti bahwa periklanan membuat konsumen sadar (aware) akan merek-merek baru, mendidik mereka tentang berbagai fitur dan manfaat merek, serta memfasilitasi penciptaan citra merek yang positif. Lalu persuading merupakan iklan yang efektif akan mampu mempersuasi (membujuk) pelanggan untuk mencoba produk dan jasa yang diiklankan yang berbentuk permintaan primer yaitu permintaan keseluruhan kategori produk dan permintaan sekunder, permintaan bagi merek perusahaan yang spesifik. Fungsi iklan selanjutya yaitu reminding yang membuat merek perusahaan tetap terjaga dan segar dalam pikiran konsumen. Selanjutnya, periklanan dapat memberi nilai tambah (adding value) pada merek dengan mempengaruhi persepsi konsumen. Adapun cara menambah nilai tersebut dengan cara inovasi, penyempurnaan kualitas, atau mengubah persepsi konsumen. Lanjut fungsi terkahir dari periklanan adalah assisting, yaitu periklanan sebagai pendamping yang memfasilitasi upaya-upaya lain dari perusahaan dalam proses komunikasi pemasaran. Perusahaan yang telah memahami fungsi-fungsi periklanan akan terus menginventasikan pengelurannya 
untuk beriklan. Namun di sisi lain perusahaan yang baikpun juga harus memahami untuk beriklan dengan efektif. Dan menurut Shimp (2000, h.416) iklan yang efektif merupakan iklan biasanya kreatif.

Kreatifitas merupakan kebutuhan perusahaan untuk beriklan. Menurut Semenik, Allen, O'Guinn, Kaufmann (2012, h. 318) pada zaman ini tidak ada perikklanan yang tidak mempertimbangkan kreatifitas. Lanjut menurut Mereka, kreatifitas merupakan sebuah kemampuan yang dapat mempertimbangkan dan menahan bersama elemen dan kekuatan yang tampaknya tidak konsisten, membuat koneksi baru. Hal tersebut mempunyai arti bahwa kreatifitas merupakan sesuatu yang unik yang muncul diluar perkiraan atau sering kita sebut dengan out of the box. Sehinga iklan membutuhkan sebuah kreatifitas guna menjadi dasar iklan yang kreatif yang dapat diingat oleh konsumen. Menurut Shimp (2000, h.416) iklan yang kreatif biasanya iklan yang bisa membedakan dirinya dari iklan-iklan massa yang sedang-sedang saja. Lanjut menurut Shimp, iklan yang sama saja dengan sebagian besar iklan lainnya tidak akan mampu menerobos kerumunan iklan kompetitif dan tidak akan dapat menarik perhatian konsumen. Hal tersebutlah yang membuat perusahaan mengurangi biaya beriklan karena dampak yang dirasakan tidak terlalu besar karena iklan yang tidak efektif. Adapun iklan kreatif membutuhkan pendekatan lebih untuk menarik perhatian konsumen dengan mempertimbangkan pesan-pesan yang disampaikan kepada konsumen yaitu dengan cara mempertimbangkan daya tarik periklanan.

Menurut Lee dan Johnson (2011, h.179) daya tarik periklanan merujuk pada basis atau pendekatan yang digunakan dalam iklan untuk menarik perhatian atau minat para konsumen dan atau untuk mempengaruhi perasaan-perasaan mereka terhadap produk, jasa atau gagasan. Lanjut, menurut mereka daya tarik dapat dibedakan menjadi beberapa kategori yaitu :
1. Daya Tarik Informasional/Rasional (Penjualan Agresif): Daya tarik ini berfokus pada kebutuhan praktis dan fungsional konsumen akan produk atau jasa.

2. Daya Tarik Emosional (Penjualan Persuasif): Daya tarik ini menggunakan pesan emosional dan dirancang di sekitar citra yang diharapkan dapat menyentuh hati.

3. Daya Tarik Kombinasi: Daya tarik ini memadukan daya Tarik informasional/rasional dan emosional. Dalam banyak situasi periklanan, spesialis kreatif tidak memilih salah satu dari kedua daya tarik tersebut, melainkan memadukan keduanya.

Setelah memahami daya tarik periklanan sebagai suatu dasar atau pendekatan beriklan yang digunakan untuk menarik perhatian konsumen, para praktisi kreatif iklan juga harus mempertimbangkan media yang dijadikan tempat untuk beriklan. Media untuk beriklan terus berkembang mulai dari penggunaan media konvensional seperti media cetak, media televisi, dan radio hingga media baru atau new media.

Perkembangan media menuju new media disebabkan oleh kehadiran dari internet. Menurut Moriarty, Mitchell, \& Wells (2009, h. 347) mejelaskan bahwa internet merupakan sistem jaringan komputer internasional yang saling terhubung dengan World Wide Web sebagai interface informasi yang memungkinkan orang untuk mengakses internet melalui format grafis yang mudah dipakai. Periklanan melalui internet terus mengalami perkembangan. Hal tersebut dibuktikan oleh Moriarty, Mitchell, \& Wells (2009, h.351) yang menyatakan bahwa advertising web site berhasil mengeruk kuntungan dua kali lipat, namun sebaliknya pertumbuhan iklan di media tradisional hanya mampu meraup keuntungan sekitar dua sampai lima persen. Hal tersebut menunjukkan bahwa fenomena iklan melalui internet terus berkembang dan membuat para praktisi periklanan menemukan cara-cara baru tentang bagaimana periklanan harus 
dikelola. Adapun salah satu praktik internet baru yang menciptakan peluang beriklan melalui internet menurut Moriarty, Mitchell, $\&$ Wells (2009, h.362) adalah webisode atau yang biasa kenal dengan sebutan webseries.

\section{YouTube}

Menurut Dacosta \& Sugandi (2017) menjelaskan bahwa YouTube termasuk salah satu dimensi baru untuk berkomunikasi yang merupakan perkembangan dari Computer Mediated Communication (CMC). Adapun pengertian YouTube menurut Karsten (2016) merupakan sebuah situs berbagi video yang dibuat oleh tiga mantan karyawan paypal pada februari 2005, yaitu, Chad Hurley, Seteve Chen, dan Jawed Karim. Lanjut, Karsten mengatakan YouTube menjadi media bagi para content creator yang dapat menggunggah video secara kreatif dan dapat terus berinovasi.

Situs berbagi video ini terus berkembang, bahkan saat ini YouTube dapat memberikan fasilitas bagi penggunanya sebagai content creator untuk mendapatkan penghasilan. Menurut Karsten (2016) hasil yang didapatkan oleh para content creator tergantung jumlah penonton (viewers) yang melihat channel content creator terkait dengan YouTube Adsense di channel YouTube mereka. YouTube Adsense merupakan iklan yang ditawarkan oleh Google Adsense kepada para pengiklan agar iklannya dapat ditampilkan di channel YouTube yang berkaitan. Menurut Arens, Weigold, \& Arens (2013, h.485) Adsense merupakan salah satu program iklan utama dari Google. Google Adsense mencoba untuk memilah dan memasukkan yang berkaitan dengan konten-konten situsnya. Salah satunya Adsense untuk YouTube bernama YouTube Adsense. Adapun menurut Karsten (2016) pendapatan yang didapatkan dari YouTube Adsense sejumlah \$0,001 per klik dari iklan tersebut.

\section{METODE PENELITIAN}

Jenis penelitian yang digunakan dalam penelitian ini adalah kualitatif dengan tataran analisis deskriptif. Penelitian kualitatif, menurut Kriyantono (2006. h. 56) memiliki tujuan untuk mengetahui sebuah fenomena sedalam-dalamnya. Ia melanjutkan bahwa riset dalam riset kualitatif yang lebih ditekankan adalah persoalan kedalaman (kualitas) data bukan banyaknya (kuantitas) data. Hal senada disampaikan oleh Basrowi (dikutip dari Wibowo 2013) yang menyatakan bahwa penelitian kualitatif adalah jenis penelitian yang menghasilkan penemuan-penemuan yang tidak dapat dicapai dengan menggunakan prosedurprosedur statistik atau dengan cara kuantifikasi lainnya. Dalam peneltian kualitiatif menurut Kriyantono (2006, h. 57) peran dari periset sangat penting dalam penelitian kualitaitf. Hal tersebut dikarenakan periset menjadi instumen riset yang harus terjun langsung di lapangan. Wibowo (2013, h.163) juga menyatakan hal yang sama bahwasannya melalui penelitian kualitatif peneliti dapat mengenali subjek dan merasakan apa yang mereka alami dalam kehidupan sehati-hari. Ia melanjutkan bahwa menurut definisi tersebut penelitian kualitatif menghasilkan data deskriptif sehingga merupakan rinci dari suatu fenomena yang diteliti.

Metode Penelitian yang digunakan dalam penelitian ini adalah metode analisis semiotika. Menurut Sobur (2003, h. 15) semiotika merupakan suatu ilmu atau metode analisis untuk mengkaji tanda. Hal senada disampaikan oleh Kriyantono (2006, h. 266) yang menyatakan bahwa analisis semiotik berupaya menemukan makna tanda termasuk hal-hal yang tersembunyi di balik sebuah tanda.

Menurut Peirce (Dikutip dari Wibowo 2013) tanda dibentuk oleh hubungan segitiga yaitu representamen atau tanda berhubungan dengan objek yang dirujuknya dan hubungan tersebut membuahkan interpretant. Adapun hubungan 
dari ketiga elemen tersebut digambarkan pada gambar 3:

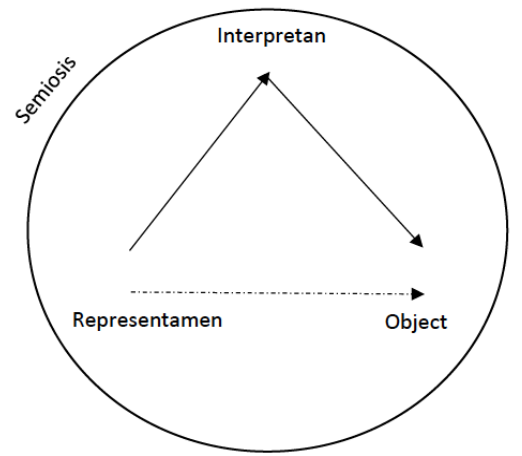

Gambar 3. Triangle of meaning

Sumber: Wibowo (2013)

Adapun yang dikupas dari teori segitiga makna tersebut menurut Kriyantono (2006, h. 267) adalah persoalan bagaimana makna muncul dari sebuah tanda ketika tanda itu digunakan seseorang pada waktu berkomunikasi.

\section{Semiotika Charles Sanders Peirce}

Menurut Sobur (Dikutip dari Wibowo, 2013) Charles Sander Peirce seringkali disebut sebagai 'grand theory' dalam semiotika. Hal tersebut disebabkan gagasan dari Peirce bersifat menyeluruh, deskripsi struktural dari semua sistem penandaan. Adapun model yang dikenalkan oleh Peirce menurut Fiske \& Littlejohn (dikutip dari Kriyantono 2006) yaitu teori segitiga makna atau triangle of meaning. Menurut Littlejohn \& Foss (2009, h. 54) kebanyakan pemikiran semiotik melibatkan ide dasar triangle of meaning tersebut. Triangle of meaning atau segitiga makna tersebut adalah representamen, objek, dan interpretant.

- Representamen: Menurut Kriyantono (2006, h. 267) tanda adalah sesuatu yang berbentuk fisik yang dapat ditangkap oleh panca indera manusia dan merupakan sesuatu yang merujuk (merepresentasikan) hal lain di luar tanda itu sendiri.

- Acuan tanda/benda (Objek): menurut Kriyantono (2006, h. 267) acuan tanda adalah konteks sosial yang menjadi referensi dari tanda atau sesuatu yang dirujuk tanda.

- Pengguna Tanda (Interpretant) : menurut Kriyantono (2006, h.267) konsep pemikiran dari orang yang menggunakan tanda dan menurunkannya ke suatu makna tertentu atau makna yang ada dalam benak seseorang tentang objek yang dirujuk sebuh tanda.

Dalam penelitian ini penggunaan segitiga makna digunakan sebagai metode analisis untuk membantu peneliti memahami representasi teori brand identity yang ada pada webseries jelang buka, Sore, dan Balada Al Prilly. Dengan menggunakan pisau analisis semiotika Peirce, Peneliti akan dapat mengetahui representasi-representasi makna dari tanda yang ditampilkan dalam iklan webseries yang terkait dengan brand identity dengan lebih mendalam.

Dalam penelitian ini peneliti menggunakan Analisa Semiotika yang dikemukakan oleh Charles Sanders Peirce. Menurut Wibowo (2013, h. 17) model semiotika milik Peirce bersifat menyeluruh, dan deskripsi struktural dari semua sistem penandaan serta Peirce ingin mengidentifikasi partikel dasar dari tanda dan menggabungkan kembali semua komponen dalam struktur tunggal sehingga hal tersebut menjadi alasan peneliti memilih model Peirce sebagai metode analisis penelitan semiotik ini. Dengan model semotika dari Peirce diharapkan peneliti dapat mengungkapkan representasi dari teori Brand identity dalam Webseries Jelang Buka, Sore, dan Balada Al Prilly.

\section{Unit Analisis Data}

Menurut Moleong (2005, h. 248) unit analisis data merupakan suatu upaya yang dilakukan dengan jalan bekerja dengan data, mengorganisasikan data, memilahmilahnya menjadi satuan yang dapat dikelola, mensistesiskan, mencari dan menemukan pola, menemukan apa yang dapat diceritakan kepada orang lain. Dengan pengertian tersebut dapat ditafsirkan bahwa unit analisis data menjadi bagian objek 
penelitian yang cukup penting yang berguna untuk diteliti satu per satu guna mencapai sutau pemahaman secara keseluruan yang dapat dijadikan panduan untuk penelitian dan pemahaman bagi yang membaca. Adapun unit analisis data dalam penelitian ini berupa screen capture tanda-tanda audio visual yang terdapat dalam webseries jelang buka, sore, dan Balada Al Prilly yang merepresentasikan unsur-unsur dalam brand identity. Potongan-potongan scene yang di screen capture tersebut dipilih berdasarkan kategori yan telah ditentukan oleh peneliti berlandaskan fokus penelitian yang telah dirumuskan peneliti dari hasil pengamatan terhadap webseries jelang buka, sore, dan Balada $\mathrm{Al}$ Prilly menggunakan unsur-unsur Teori Brand identity dari Aaker yaitu Brand as Product, Brand as Organization, Brand as Person, dan Brand as Symbol . Terdapat empat episode yang akan dianlisis di webseries Jelang Buka yaitu episode 1, episode 2, episode 3, dan episode 4.

Selanjutnya di webseries Sore terdapat empat webseries yang akan dianlisis peneliti yaitu episode 1 , episode 4 , episode 7 dan episode 9. Dan pada webseries Balada Al Prilly terdapat tiga episode yang akan dinalisis oleh peneliti yaitu episode 1 , episode 2, dan episode 3.

\begin{tabular}{|c|c|c|c|c|}
\hline & Judul Webseries & $\begin{array}{l}\text { Perspektif brand } \\
\text { identity } \\
\text { dari David A. } \\
\text { Aaker } \\
\end{array}$ & Dimensi & Scene (Adegan) \\
\hline \multirow[t]{12}{*}{ a. } & Jelang Buka & Brand as Product & Product Scope & \\
\hline & & & Product attributes & \\
\hline & & & Quality/value & \\
\hline & & & Uses & \\
\hline & & & Users & \\
\hline & & & Country of origin & \\
\hline & & $\begin{array}{l}\text { Brand as } \\
\text { organization }\end{array}$ & $\begin{array}{l}\text { Organization } \\
\text { attributes }\end{array}$ & \\
\hline & & & Local vs Global & \\
\hline & & Brand as Person & Brand personality & \\
\hline & & & $\begin{array}{l}\text { Brand customer } \\
\text { relationship }\end{array}$ & \\
\hline & & Brand as Symbol & $\begin{array}{l}\text { Visual } \\
\text { Imagery/methaphors }\end{array}$ & \\
\hline & & & Brand heritage & \\
\hline \multirow[t]{8}{*}{$\mathrm{b}$} & Sore & Brand as Product & Product Scope & \\
\hline & & & Product attributes & \\
\hline & & & Quality/value & \\
\hline & & & Uses & \\
\hline & & & Users & \\
\hline & & & Country of origin & \\
\hline & & $\begin{array}{l}\text { Brand as } \\
\text { organization }\end{array}$ & $\begin{array}{l}\text { Organization } \\
\text { attributes }\end{array}$ & \\
\hline & & & Local vs Global & \\
\hline
\end{tabular}




\begin{tabular}{|c|c|c|c|c|}
\hline & & Brand as Person & Brand personality & \\
\hline & & & $\begin{array}{l}\text { Brand customer } \\
\text { relationship }\end{array}$ & \\
\hline & & Brand as Symbol & \begin{tabular}{|l|} 
Visual \\
Imagery/methaphors
\end{tabular} & \\
\hline & & & Brand heritage & \\
\hline \multirow[t]{12}{*}{$\mathrm{c}$} & Balada Al Prilly & Brand as Product & Product Scope & \\
\hline & & & Product attributes & \\
\hline & & & Quality/value & \\
\hline & & & Uses & \\
\hline & & & Users & \\
\hline & & & Country of origin & \\
\hline & & $\begin{array}{l}\text { Brand as } \\
\text { organization }\end{array}$ & $\begin{array}{l}\text { Organization } \\
\text { attributes }\end{array}$ & \\
\hline & & & Local vs Global & \\
\hline & & Brand as Person & Brand personality & \\
\hline & & & \begin{tabular}{|l} 
Brand customer \\
relationship
\end{tabular} & \\
\hline & & Brand as Symbol & \begin{tabular}{|l} 
Visual \\
Imagery/methaphors
\end{tabular} & \\
\hline & & & Brand heritage & \\
\hline
\end{tabular}

Tabel 4. Tabel Kategorisasi Brand Identity Sumber Data Olahan Peneliti

Adapun potongan-potongan scene tersebut akan dianalisis menggunakan kerangka semiotika Charles Sanders Peirce. Peirce akan menganalisis tanda-tanda menggunakan teori triangle of meaning yaitu Representamen, objek, dan interpretant.

\section{Sumber Data}

Data yang didapatkan dari penelitian ini adalah data teks. Menurut Kriyantono (2006, h. 38) data ini biasa digunakan pada penelitian yang membahas sistem tanda. Adapun sumber data primer yang digunakan peneliti adalah video dokumentasi yang dapat diunduh di akun resmi Tropicana Slim, Unilever, dan Vivo Indonesia di platform YouTube. Adapun jumlah video yang diteliti sebanyak 15 video webseries. Dan data sekunder yang digunakan oleh peneliti berasal dari literatur yang terdapat di media cetak dan media elektronik yang memiliki relevansi dengan topik pembahasan.

\section{Teknik Pengumpulan Data}

Menurut Kriyantono (2006, h. 95)

Teknik pengumpulan data adalah teknik atau cara-cara yang dapat digunakan periset untuk mengumpulkan data. Adapun teknik pengumpulan data yang digunakan dalam meneliti representasi brand identity dalam webseries Jelang buka, Sore, dan Balada Al Prilly menggunakan metode dokumentasi yaitu video webseries jelang buka, sore, dan Balada $\mathrm{Al}$ prilly melalui pengidentifikasian tanda-tanda yang ada pada ketiga webseries tersebut berupa visual dan audio. Menurut Kriyantono (2006, h. 120) dokumen bisa berbentuk dokumen publik atau dokumen privat. Dokumen yang dilakukan peneliti berasal dari dokumen publik karena video- 
video webseries tersebut dapat diakses Bersama-sama melalui YouTube.

Adapun aspek visual dan audio yang berasal dari konsep sinematografi digunakan untuk mempermudah peneliti dalam melakukan proses transkrip sebagai tambahan data untuk di interpretasi. Peneliti menggunakan tabel transkrip sebagai cara untuk melihat bagaima konsep-konsep dari brand identity direpresentasikan melalui webseries Jelang Buka, Sore, dan Balada Al Prilly. Tabel transkrip dalam proses penelitian yang digunakan adalah sebagai berikut :

\begin{tabular}{|l|l|l|l|l|l|l|}
\hline Screenshot & \multicolumn{3}{|c|}{ Visual } & \multicolumn{3}{c|}{ Audio } \\
\cline { 2 - 7 } (Scenes) & Type of & Camera & Setting & Dialog & Music & Sound \\
& Shot & angle & & & & Effect \\
\hline
\end{tabular}

Tabel 5 Tabel transkrip audiovisal

Sumber : Diadaptasi dari Skripsi Representasi Tokoh Antagonis Dalam Film The Dark Knight (Studi Semiotik Tokoh Joker dalam Film The Dark Knight)

Tabel 5 tersebut yang akan digunakan oleh Peneliti sebagai data untuk membedah scene-scene dalam webseries Jelang Buka, Sore, dan Balada Al Prilly yang difokuskan terhadap unsur-unsur yang merepresentasikan brand identity di dalam cerita webseries tersebut.

\section{Teknik Analisis Data}

Menurut Afrizal (2014, h. 176) analisis data dalam penelitian kualitatif adalah aktivitas yang dilakukan secara terusmenerus selama penelitian berlangsung, dimulai dari mengumpulkan data sampai pada tahap penulisan laporan. Ia menambahkan bahwa dalam penelitian kualitatif, pengumpulan data dan analisis data bukanlah dua hal yang terpisah namun dilakukan secara bersamaan. Teknik analisis data yang digunakan dalam penelitian ini menggunakan teknik analisis semiotika Peirce dengan tahapan-tahapan proses penelitian dari Miles and Huberman yaitu pengumpulan data, reduksi data, dan penyajian data serta kesimpulan. Model Miles dan Huberman digunakan sebagai pedoman peneliti dalam menganalisis teks menggunakan Analisis Semiotika Peirce.
Adapun proses peneliti melakukan analisis data adalah berawal dari panduan yang telah dibuat melalui unit analisis data yaitu kategorisasi dari adegan-adegan (Scenes) yang mengindikasikan adanya unsur-unsur representasi brand identity. Setelah itu peneliti melakukan pembedahan adegan-adegan (scenes) ke dalam tabael transkrip yang telah dilakukan sebelumnya melalui data visual (angle, shot dan setting) dan audio (dialog, musik, dan sound effect). Lalu setelah adegan-adegan di transkrip, proses analisis semiotika Charles Sanders Peirce pun dimulai. Instrumen analisis (Tabel 6) semiotika Peirce yang digunakan dalam penelitian ini adalah :

\begin{tabular}{|l|l|l|}
\hline Representamen & Objek & Interpretant \\
$/$ & & \\
Sign & & \\
\hline & & \\
\hline
\end{tabular}

Tabel 6. Instrumen analisis semiotika Peirce Sumber: (Sobur, 2003)

Dengan menggunakan instrumen tersebut, peneliti membedah makna-makna representasi brand identity dalam webseries 
jelang buka, Sore, dan Balada Al Prilly. Adapun representamen yang dimaksudkan dalam penelitian ini adalah potongan gambar dari adegan (scene) yang ada pada webseries Jelang Buka, Sore, dan Balada Al Prilly yang dianggap mewakili unsur-unsur brand identity yang ditampilkan dalam iklan webseries tersebut. Objek dalam penelitian ini adalah keselurahan unsur yang ada di dalam adegan tersebut. Dan aspek interpretant merupakan aspek peneliti dalam mengartikan tanda-tanda yang ada. Interprestasi penulis juga perlu melihat konteks sosial yang ada di masa webseries tersebut tayang untuk menyesuaikan tujuan dari makna simbol tersebut dibuat. Setelah itu, peneliti melakukan analisis secara deskriptif untuk menggambarkan secara rinci hubungan antara tanda, objek, dan interpretant pada representasi brand identity dalam webseries Jelang Buka, Sore, dan Balada Al Prilly sebagai media alternatif periklanan. Setelah itu peneliti akan membuat kesimpulan berdasarkan hasil analisa yang telah dilakukan peneliti mengenai representasi dari brand identity yang ada pada media kreatif periklanan webseries Jelang Buka, Sore, dan Balada $\mathrm{Al}$ Prilly.

\section{HASIL DAN PEMBAHASAN}

\section{Webseries sebagai media alternatif periklanan}

Menurut Moriarty, Mitchell \& Wells (2009, h.364) Webisode atau yang biasa disebut Webseries merupakan bentuk baru dari advertising web yang mirip dengan acara televisi yang menayangkan cerita serial. Webseries merupakan sebuah konsep acara berseri yang dirilis melalui internet, biasanya ditayangkan melalui platform YouTube, Vimeo dan website. Menurut Puspasari (2017) keberadaan webseries dianggap sebagai peluang bagi perusahaan sebagai media alternatif untuk beriklan. Menurutnya alasan webseries menjadi sebuah alternatif media periklanan dikarenakan webseries memiliki penonton yang lebih terukur dan terarah dibadingkan dengan iklan yang ada di televisi. Dan fitur terbaru dalam platform tertentu sebagai tempat tayangnya webseries adalah kolom komentar (comment box), sehingga feedback yang didapatkan bisa lebih cepat dan lebih interaktif.

Adapun webseries yang dibahas dalam penelitian ini terdapat 3 webseries yang berjudul Balada Al Prilly, Jelang Buka, dan Sore. webseries Balada Al Prily merupakan webseries besutan Vivo Indonesia yang memiliki 3 episode dengan jumlah penonton sebanyak 7.197.662 orang. webseries ini menceritakan tentang pesan moral di setiap episodenya. Lalu yang kedua terdapat webseries berjudul Jelang Buka besutan Unilever dengan jumlah penonton sebanyak 13.402.380. Webseries ini menceritakan hubungan antara menantu dan mertua yang tinggal bersama selama bulan Ramadhan. Lalu yang ketiga adalah webseries berjudul Sore besutan Tropicana Slim yang memiliki jumlah penonton sebanyak 9.600.075 orang. Webseries ini menggaungkan kampanye hidup sehat dalam alur ceritanya. Semua webseries ini ditayangkan melalui sebuah platform berbagi video bernama YouTube.

Menurut Jefkins dalam Yusuf (2010) menjelaskan bahwa periklanan sebagai pesan penjualan yang paling persuasive dan ditargetkan kepada pembeli potensial terkait produk yang telah ditetapkan dengan biaya serendah-rendahnya. Adapun periklanan mengalami perkembangan terus-menerus seiring dengan berkembangnya teknologi yaitu munculnya internet. Periklanan menggunakan internet terus mengalami perkembangan, seperti yang disampaikan oleh Moriarty, Mitchell, \& Wells (2009, h.351).

Menurut Puspasari (2017) keberadaan webseries dianggap sebagai peluang bagi perusahaan sebagai media alternatif untuk beriklan. Adapun alasan webseries dijadikan media alternatif periklanan dikarenakan websereis memiliki penonotn yang lebih terukur dan terarah karena webserieswebseries tersebut ditampilkannya melalui Youtube. Youtube memiliki fitur untuk beriklan sendiri yaitu menggunakan youtube 
adsense. Namun dalam perkembangannya, berbagai merek pun ikut membuat channel dan membuat konten video sendiri tanpa menggunakan Youtube adsense.

Ketertarikan masyarkat yang menonton webseries hingga memiliki jumlah penonton jutaan yang membuat brand atau merek ingin terus menggunakan webseries sebagai media alternatif periklanannya selain itu menurut Rahayu (2017) banyak keuntungan membuat webseries yang salah satunya video produksi yang lebih murah dibandingkan pembuatan iklan untuk TVC. Itulah alasan mengapa webseries dijadikan media alternatif periklanan yang cukup digemari bagi untuk brand maupun penontonnya.

Adapun di tahun 2017 terdapat tiga webseries yang mempunyai jumlah penonton terbanyak dan yang juga sedang peneliti analisis yaitu webseries Jelang Buka dari Unilever, webseries Sore dari Tropicana Slim, dan webseries Balada Al Prilly dari Vivo. Dari hasil observasi Peneliti, didapatkan hasil bahwa webseries Jelang Buka, Sore, dan Balada Al Prilly memunculkan identitas brandnya di dalam cerita rersebut.

Identitas merek yang dimunculkan meliputi empat perspektfi yaitu brand as product, brand as organization, brand as person dan brand as symbol. Webserieswebseries tersebut dikemas dengan cara yang berbeda-beda dalam memunculkan identitas mereknya ada yang secara tersurat menampilkan fungsi dan kegunaan dari produknya adapula yang menapilkan identitas mereknya melalui ceritanya. Adapun perspektif yang telah dianalisis oleh Peneliti adalah sebagai berikut :

\section{Brand as Product}

Ketiga webseries tersebut memunculkan perspektif brand as product. Namun dimensi yang dimunculkan berbedabeda. Jelang Buka menggunakan dimensi product scope dan users ke dalam ceritanya, sementara Sore dan Balada Al Prilly hanya menggunakan dimensi product attribute.
Menurut Aaker (dikutip dari Gultom 2014) dimensi product scope membahas tentang dengan apa sebuah brand di asosiasikan. Jelang Buka menjadi satusatunya webseries yang menggunakan product scope di dalam ceritanya. Jelang Buka seringkali menggunakan adeganadegan yang bersifat mengasosiasikan produk dari Unilever dengan nama asli dari jenis produk tersebut. Sebagai contoh pasta gigi digati dengan nama Pepsodent, jus asli diasosiasikan dengan jus kemasan bermerek Buavita. Sehingga hal tersebut dapat mengasosiasikan penonton bahwa produk tersebut sebagai pengganti nama asli dari jenis produk tersebut.

Lalu dimensi users menurut Aaker (dikutip dari Gultom 2014) mempunyai arti sebuah identitas yang berkaitan dengan tipe pengguna brand atau produk. Webseries Jelang Buka memperlihatkan adegan-adegan yang menunjukkan produk-produk dari Unilever itu sesuai dengan konsumennya, seperti parfum Axe dipakai Arief Muhammad yang berarti penggunanya adalah laki-laki yang modern, kreatif dan mandiri. Lalu Produk fair \& lovely dan Vaseline yang digunakan oleh Tipang yang berarti penggunanya diperuntukan untuk perempuan yang peduli tentang perawatan diri dan kecantikan. Lalu produk Royco dan kecap Cap Bango yang diguunakan oleh Tipang dan Mamahnya Arief yang berarti produknya diperuntukkan untuk perempuan yang mempunyai hobi di bidang kuliner.

Dimensi terakhir yang muncul di perspektif brand as product adalah product attribute. Menurut Aaker (dikutip dari Gultom 2014) product attributes merupakan sebuah identitas yang menunjukkan pembelian atau penggunaan produk yang dapat memeberikan manfaat fungsional dan emosional. Webseries Sore menunjukkan di kedua adegan tentang penggunaan Product Tropicana Slim Stevia untuk orang-orang yang sehat sehingga cocok digunakan untuk hidup yang lebih sehat. Lalu di webseries Balada Al Prilly menunjukkan identitas mereknya tentang product attribute yaitu penggunaan kamera Vivo Vs5 untuk 
melakukan swafoto untuk mengabadikan momen-momen penting seperti ulang tahun, hari pahlawan dan saat berkumpul Bersama keluarga.

\section{Brand as Organization}

Hanya terdapat satu webseries yang menggunakan perspektif ini yaitu webseries Jelang Buka dengan dimensi organziation attribute. Menurut Aaker (dikutip dari Gultom 2014) organization attributes mempunyai arti dengan sebuah brand yang lebih mengutamakan atribut atau nilai perusahaan dibandingkan dengan produk atau jasa. Webseries Jelang Buka memunculkan adegan-adegan yang mewakili dari nilai-nilai perusahaan untuk disampaikan kepada penonton seperti saat Arief menyampaikan penyambutan bulan suci Ramadhan dengan menggunakan warna baju yang sama dengan warna Unilever dan saat Tipang meyampaikan pesan dari cerita untuk menjadi versi terbaik diri sendiri. Arief dan Tipang sebagai pemeran utama diharapkan menjadi perwakilan dari Unilever dalam menyampaikan pesan di bulan Suci Ramadhan

\section{Brand as Person}

Ketiga webseries tersebut menggunakan brand as person sebagai identitas merek yang dimunculkan di dalam cerita webseries. Tedapat dua dimensi yang dimunculkan dari perspektif brand as person yaitu dimensi brand personality dan brand customer relationship.

Menurut Aaker (dikutip dari Gultom

2014) Brand personality mempunyai arti sebagai penciptaan karakter atau kepribadian brand dalam rangka menguatkan brand. Webseries yang menggunakan dimensi brand personality adalah Sore dan Balada Al Prilly. Webseries Sore memperllihatkan adeganadegan yang menunjukkan sifat Sore sebagai pemeran utama yang mempunyai hidup sehat dan ingin mengubah hidup Jonathan menjadi lebih sehat. Setiap kegiatan Sore diceritakan secara rinci seperti membuang minuman beralkohol, membuang rokok, mengaharuskan Jonathan untuk lari pagi selama dua puluh menit, dan pola makan dan hidup sehat yang menjadikan sifat Sore yang mewakili brand Tropicana Slim yang mengaharuskan konsumennya untuk hidup sehat. Sementara di webseries Balada $\mathrm{Al}$ Prilly menunjukkan adegan-adegan dari Mini $\mathrm{V}$ yang diperankan oleh Al yang sedang menyapa penumpang di seluruh bis sehingga semua terseyum dan tertawa melihat mini-v. Sifat Mini-V yang ramah, menyenangkan dan bersahabat ini yang ingin dijadikan brand personality dari Vivo.

Dimensi selanjutnya adalah dimensi Brand Customer Relationship. Menurut Aaker (dikutip dari Gultom 2014) Brand Customer Relationhip mempunyai arti bahwa identitas merek berkaitan dengan kepribadian brand yang dapat membantu mengkomunikasikan manfaat fungsional. Terdapat beberapa adegan dari webseries Jelang Buka yang membantu mengomunikasikan fungsi dari produk seperti saat Tipang mencoba masakan yang diberi bumbu Royco dan kecap Cap Bango, kemudian Tipang mengatakan makanan tesebut enak. Lalu saat Tipang mencium bau wangi jilbab Raisa setelah Raisa mengatakan bahwa jilbabnya menggunakan produk Molto White Musk dan terakhir saat Tipang mengatakan bahwa Ia menyukai Ice Cream walls rasa coklat dan mamahnya Arief pun mengatakan demikian sehingga penonton melihat rasa coklat ice cream walls memang sangat enak. Adegan-adegan tersebut membantu mengkomunikasikan manfaat fungsional dan emosional yang dapat akan dirasakan penonton apabila penonton menggunakan produk tersebut.

\section{Brand as Symbol}

Ketiga webseries tersebut meggunakan perspetif brand as symbol dengan dimensi yang sama yaitu visual imagery/methaphors. Webseries Jelang Buka menunjukkan produk-produk yang diperilhatkan dalam webseries Jelang Buka yang merupakan produk untuk keperluan sehari-hari seperti Pepsodent pasta gigi, Pepsodent sikat gigi, sabun mandi Lifebuoy, parfum Axe, Fair \& Lovely cream, Vaseline, 
Buavita, Royco, kecap Cap Bango dan ice cream Walls. Semua produk tersebut masuk kedalam kategori produk keperluan seharihari atau biasa disebut sebagai consumer daily goods. Lalu webseries Sore memperlihatkan adegan-adegan yang menunjukkan bahwa produknya masuk kedalam kategori produk untuk gaya hidup sehat. Hal tersebut dapat dilihat saat Sore dan Jonathan selaku pemeran utama menggunakan produk Tropicana Slim Stevia yang digunakan di minuman mereka menunjukkan bahwa mereka sedang melakukan gaya hidup sehat. Lalu webseries terakhir adalah webseries Balada Al Prilly yang mengkategorisasikan produknya kedalam produk untuk gaya hidup manusia modern yaitu yang selalu mengabadikan momen-momen penting dengan melakukan swafoto dengan telepon seluler Vivo Vs5.

\section{SIMPULAN}

Dalam webseries di Youtube, nilainilai periklanan yang dimunculkan dalam webseries tidak lepas dari perspektifperspektif brand identity yang dikemukakan oleh Aaker. Brand identity merupakan elemen penting dalam sebuah periklanan. Oleh sebab itu, ketiga webseries yang telah dibahas oleh Peneliti yaitu webseries Jelang Buka, Sore, dan Balada Al Prilly tidak lepas dari unsur yang ada pada brand identity seperti brand as product, brand as organization, brand as person dan brand as symbol. Ketiga webseries dipilih berdasarkan viewers terbayak di tahun 2017 yang memiliki fokus pesan dan karakteristik yang berbeda-beda. Keempat perspektif brand identity direpresentasikan melalui peranan dan fungsi yang sangat penting di setiap webseriesnya. Meskipun webseries ini berbeda dengan periklan konvensional tetapi unsur brand identity tetap melekat pada webseries tersebut dan direpresentasikan sesuai dengan nilai-nilai brand yang ada melalui sebuah cerita yang dikemas secara kreatif dan menarik. Seperti Tropicana Slim dengan identitasnya yang dikemas dalam bentuk kampanye hidup sehat, lalu Unilever dengan identitasnya yang memunculkan produk-produknya untuk kebutuhan seharihari para konsumen, dan Vivo memiliki identitas sebagai brand yang modern dengan munculnya produk Vivo Vs5 dengan kamera yang bagus untuk melakukan swafoto untuk mengabadikan setiap momen-momen penting konsumennya.

Penyampaian pesan dan kegunaan produk yang ditampilkan dalam webseries dilakukan baik secara implisit maupun eksplisit. Bentuk penyampaian secara implisit dilakukan oleh Tropicana Slim dengan mencanangkan hidup sehatnya melalui cerita yang dikemas dalam bentuk drama, sehingga hal tersebut dianggap menarik bagi penonton. Berdasarkan unit yang diteiti, produk Tropicana Slim hanya dimunculkan pada satu episode dari Sembilan episode yang ada sehingga dapat diketahui bahwa Webseries Tropicana Slim lebih mengutamakan cerita yang dikemas secara kreatif sehingga penonton banyak yang menyukai jalan cerita dari webseries Sore tersebut. Selanjutnya Unilever dan Vivo cukup eksplisit dalam menampilkan produk-produknya di setiap episodenya. Hal tersebut dapat dilihat produk-produk dari Unilever hamper muncul di setiap episodenya dan produk Vivo Vs5 yang selalu hadir di setiap episode dengan selalu melakukan swafoto di akhir adegan di setiap episodenya.

\section{DAFTAR PUSTAKA}

Aaker (1995) Building Stong

Brand. USA:Free Press

Ad Format On Youtube. (2015). Diakses pada tanggal 3 Januari 2018, dari https://creatoracademy.youtube.c

om/page/lesson/ad-types.

Afrizal. (2014). Metode Penelitian Kualittaif:Sebuah Upaya Mendukung Penggunaan Penelitian Kualitatif Dalam Berbagai Disiplin Ilmu. Depok:RajaGrafindo Persada.

Alfajri, I., Irfansyah, Isdianto, B. (2014). Analisis Web Series Dalam Format Film Pendek (Studi Kasus Web Series 'Malam Minggu Miko Episode Nissa'). 
Jurnal Komunikasi Visual

Multimedia, 6(1), 27-39.

Aliya. (2018). Pengertian Youtube Beserta Manfaat dan Fitur-fitur Youtubeyang perlu Anda Ketahui. Diakses pada tanggal 3 Januari 2018, dari https://www.nesabamedia.com/pe ngertian-youtube/.

Amedie, J. (2015). The Impact of Social Media on Society. (Tesis Magister, Santa Clara University, 2015).

Arens, W. F., Weigold, M. F. \& Arens, C. (2013). Contemporary Advertising and Integrated Marketing Communications (14 ${ }^{\text {thed.). }} \quad$ NewYork:McGraw-Hill,

Berger, A. A. (2012). Seeing is Believing :An Introduction to Visual Communication $\left(4^{\text {th }}\right.$ ed.). New York : McGrawHill.

Dacosta, M., D. \& Sugandi, M., S. (2017). Strategi Kreatif Iklan Dalam Pemanfaatan Webseries (Studi Kasus Axelerate: The Series Axe Indonesia Oleh Makna Creative). e-Proceeding of Marketing, 4(1), 1150-1155.

Digital in2017. (2017). Diakses pada tanggal 29 Desember 2017, dari https://wearesocial.com/specialreports/digital-in-2017-global-overview.

Gultom, N. S. W. (2014). Analisis Proses Pembentukan Corporate Brand, Brand Identity dan Brand Awarness Melalui Online Branding (Studi Kasus Jakarta Post Travel). (Tesis Magister, University of Indonesia, 2014).

Hariningsih, E. \& Munarsih, E. (2014). Analisis perilaku penghindaran iklan internet oleh konsumen. Jurnal Siasat Bisnis, 18(2), 180-189.

Karsten, S. (2016). Pengertian Youtube itu apa? Terlengkap. Diakses pada tanggal 8 Januari 2018, dari https://imersmuda.com/pengertian youtube-itu-apa/.

Kriyantono, R. (2006). Teknik Praktis Riset Komunikasi : Disertai Contoh Praktis Riset Media, Public Relations, Advertising, Komunikasi Organisasi, Komunikasi Pemasaran. Jakarta:Kencana.

Lee, M. \& Johnson, C. (2011). PrinsipPrinsip Pokok Periklanan Dalam
Perspektif Global. (H. Munandar \& D. Priatna, Terjemahan). Jakarta : Kencana.

Littlejohn, S. W. \& Foss, K. A. (Eds). (2009). Teori Komunikasi $\left(9^{\text {th }}\right.$ ed.). (M.Y.Hamdan, Terjemahan). Jakarta:Salemba Humanika.

Mar'athussoilikah, A. L. (2017). Penggambaran Maskulinitas Dalam Sudut Pandang New Media (Analisis Semiotika Pada Webseries "Axelerate The Series :The untold Story”). (Skripsi Sarjana, Brawijawa University, 2017)

Moleong, L. J. (2005). Metodologi Penelitian Kualitatif. Bandung: Remaja Rosdakarya.

Moriarty, S., Mitchell, N. \& Wells, W. (2009). Advertising ( $8^{\text {th }}$ ed.). (T.Wibowo, Terjemahan). Jakarta : Kencana.

Musfar, T.F. (2004). Analisis Pengaruh Endorser Personality Terhadap Brand Personality : Studi Kasus Penggunaan Selebriti dan non-selebriti sebagai Endorser produk pembalut wanita merek Kotex. Diakses pada 4 Juli 2018 dari http://etd.repository.ugm.ac.id/ind ex.php?mod=Penelitian_detail \&sub=Pene litianDetail\&act $=v i e w \& t y p=h t m l \& b u k u \_i$ $d=24988 \&$ obyek_id $=4$

Nurani, E.S. dan Haryanto, J.O. (2010). Diakses pada 5 Juli 2018 dari http://journal.binus.ac.id/index.ph p/JBSE/article/viewFile/197/193

Nurrofiq, M. (2012). Pengertian Perikalan/Promosi (Advertising). Diakses pada tanggal 7 Januari 2018, dari http://www.diwarta.com/2012/04/05/penge rtian-periklanan-promosiadvertising.html.

Phillips, B. J., McQuarrie, E. F., Griffin, W. G. (2014). How Visual Brand Identity Shapes Consumer Response. Psychology and Marketing, 31(3), 225-236.

Rahayu, E. S. (2017). Perkembangan Web Series Indonesia. Diakses pada tanggal 28 Desember 2017, dari http://www.epic creativehouse.com/2017/01/perkembangan - web-series-indonesia.html.

Sadat, A. M. (2009). Brand Belief: Strategi Membangun Merek Berbasis Keyakinan. Jakarta: Salemba Empat. 
Semenik, R. J., Allen, C.T., O’Guinn, T.C. \& Kaufmann, H. R. (2012) Advertising and Promotions An Integrated Brand Approach(6 $6^{\text {thed. }}$.). Australia: SouthWestern.

Shimp, T. A. (Eds). (2000). Periklanan Promosi dan Aspek Tambahan Komunikasi Pemasaran Terpadu ( $5^{\text {th }}$ ed.). (R. Sjahrial $\&$ D.Anikasari, Terjemahan).Indonesia: Erlangga.

Sobur, A. (2003). Semiotika Komunikasi. Bandung : Remaja Rosdakarya.

Web Series, Alternatif Menonton Film Selain Di Bioskop. (2017). Diakses pada tanggal 28 Desember 2017, dari http://hiburan.metrotvnews.com/fi $\mathrm{lm} /$ zNAG5w6k-web-series-alternatifmenonton-film-selain-di-bioskop.

Wibowo, I. S. W. (2011). Semiotika Komunikasi-Aplikasi Praktis Bagi Penelitian dan Skripsi Komunikasi (2nded.). Jakarta : Mitra Wacana Media.

Widharma, I., W. (2015). Pengertian Shot, Scene, dan Sequence. Diakses pada tanggal 10 Januari 2018, dari http://csinema.com/shot-scene-dansequence/.

Widyawati, A. (2017). Representasi Peran Gender Dalam Film India (Analisis Semiotika Roland Barthes Pada Tokoh Kabir Dalam Film KI AND KA (2016)). (Skripsi Sarjana, Brawijaya University,2017)

Yani,T. K. (2017). Alternatif Film bagi Masyarakat. Diakses pada tanggal 28 Desember 2017, dari http://www.mediaindonesia.com/news/rea d/98968/alternatif-film-bagimasyarakat/2017-04-02.

Yuniar, N. (2015). Pertumbuhan video Youtube Indonesia terbesar Asia Pasifik. Diakses pada tanggal 29 Desember 2017, dari https://www.antaranews.com/berit a/524666/pertumbuhan-video-youtubeindonesia-terbesar-asia-pasifik.

Yusuf. (2017). Pengertian Periklanan dan Fungsi Periklanan Dlam Manajemen. Diakses pada tanggal 8 Januari 2018, dari http://jurnalmanajemen.com/peng ertianperiklanan/. 